\title{
Amino-terminal extension present in the methionine aminopeptidase type 1c of Mycobacterium tuberculosis is indispensible for its activity
}

Pavitra Kanudia, Monica Mittal, Sangaralingam Kumaran and Pradip K Chakraborti ${ }^{*}$

\begin{abstract}
Background: Methionine aminopeptidase (MetAP) is a ubiquitous enzyme in both prokaryotes and eukaryotes, which catalyzes co-translational removal of N-terminal methionine from elongating polypeptide chains during protein synthesis. It specifically removes the terminal methionine in all organisms, if the penultimate residue is non-bulky and uncharged. The MetAP action for exclusion of N-terminal methionine is mandatory in 50-70\% of nascent proteins. Such an activity is required for proper sub cellular localization, additional processing and eventually for the degradation of proteins.
\end{abstract}

Results: We cloned genes encoding two such metalloproteases (MtMetAP1a and MtMetAP1c) present in Mycobacterium tuberculosis and expressed them as histidine-tagged proteins in Escherichia coli. Although they have different substrate preferences, for Met-Ala-Ser, we found, MtMetAP1c had significantly high enzyme turnover rate as opposed to MtMetAP1a. Circular dichroism spectroscopic studies as well as monitoring of enzyme activity indicated high temperature stability (up to $50^{\circ} \mathrm{C}$ ) of MtMetAP1a compared to that of the MtMetAP1c. Modelling of MtMetAP1a based on MtMetAP1c crystal structure revealed the distinct spatial arrangements of identical active site amino acid residues and their mutations affected the enzymatic activities of both the proteins. Strikingly, we observed that 40 amino acid long N-terminal extension of MtMetAP1C, compared to its other family members, contributes towards the activity and stability of this enzyme, which has never been reported for any methionine aminopeptidase.

Furthermore, mutational analysis revealed that Val-18 and Pro-19 of MtMetAP1c are crucial for its enzymatic activity. Consistent with this observation, molecular dynamic simulation studies of wild-type and these variants strongly suggest their involvement in maintaining active site conformation of MtMetAP1C.

Conclusion: Our findings unequivocally emphasized that N-terminal extension of MtMetAP1C contributes towards the functionality of the enzyme presumably by regulating active site residues through "action-at-a-distance" mechanism and we for the first time are reporting this unique function of the enzyme.

\section{Background}

The N-terminal methionine excision (NME) is an essential co-translational proteolytic process responsible for the diversity of amino-termini of proteins in both prokaryotes and eukaryotes [1]. It is an irreversible reaction, which occurs soon after N-terminal residues of the nascent polypeptide chain emerge from the ribosome exit tunnel

\footnotetext{
* Correspondence: pradip@imtech.res.in

Institute of Microbial Technology, Council of Scientific and Industrial Research, Sector 39A, Chandigarh 160 036, India
}

before the commencement of protein folding [2]. The enzyme involved in the process is known as methionine aminopeptidase (MetAP), which specifically removes the terminal methionine in all organisms, if the penultimate residue is non-bulky and uncharged [3]. In prokaryotes and eukaryotic organelles where the initiator methionine is formylated, NME requires the action of another metalloprotease, peptide deformylase in addition to MetAP, which removes the $\mathrm{N}$-formyl group present on all synthesized nascent polypeptides. In fact, removal of $\mathrm{N}$-formyl group is a prerequisite for the subsequent action of 
MetAP [4]. Nevertheless, the MetAP action for exclusion of N-terminal methionine is mandatory in $50-70 \%$ of nascent proteins. Such an activity is required for proper sub cellular localization, additional processing and eventually for the degradation of proteins [5].

MetAPs are ubiquitous in distribution and are highly conserved throughout the phylogeny. They were initially grouped in two classes, MetAP1 and MetAP2 on the basis of sequence comparison. The type 2 enzymes, in contrast to type 1 , have an approximately 60 amino acid long $\alpha$ helical domain inserted within the catalytic region of the enzyme [6,7]. This helical sub-domain shares neither sequence nor structural homology with any other known protein. The MetAPs are further divided in two subclasses on the basis of absence (subclass a) or presence (subclass b) of $\mathrm{N}$-terminal extension [8]. The N-terminal extension present in type $1 \mathrm{~b}$ contains two zinc finger motifs while that of type $2 b$ has alternate stretches of polyacidic and polybasic residues. Recently, two new subclasses, type 1c and 2c, have been introduced where $\sim 40$ amino acid long $\mathrm{N}$-terminal extension is present but zinc finger motif is absent $[9,10]$.

Apart from several types of MetAPs, presence of more than one copy of functional genes encoding this enzyme has been reported in both prokaryotes and eukaryotes. In human, there are two such well characterized enzymes, which have been shown to be involved in cell proliferation $[11,12]$. Among four isoforms of MetAPs in Plasmodium falciparum, three exhibited enzymatic activities [13]. Genetic studies further established the essentiality of this enzyme in both prokaryotes and eukaryotes [14-16]. These findings led to the assumption that MetAP would be an ideal drug target and screening/designing of inhibitors against this enzyme might help in planning to combat the problem of rapid resurgence of diseases due to emergence of drug resistant strains of different pathogens. In this context, we focussed on tuberculosis, which is caused by Mycobacterium tuberculosis, and responsible for considerable human mortality throughout the world in recent years.

Although bacteria generally have single MetAP1, mycobacterial genome revealed the presence of 2-4 putative genes for MetAP1; for instance M. tuberculosis has two genes mapA (Rv0734) and mapB (Rv2861c) encoding $M t$ MetAP1a and $M t$ MetAP1c respectively. Although, crystal structure of MtMetAP1c was solved as an apoenzyme and in complex form [9], biochemical characterization of the two MtMetAPs has not been reported until very recently [17-21]. However, detailed structure-function analysis of these enzymes has not yet been carried out. In this scenario, we concentrated on both these $M t$ MetAP1s and in this article we report their distinct characteristics. Furthermore, we provide here evidence that catalytic domain of MtMetAP1c alone is not sufficient for the enzyme activity.

\section{Results \\ MtMetAP1a and MtMetAP1c exhibit subtle difference in their behaviour}

The mapA and mapB genes from $M$. tuberculosis were PCR amplified, cloned in pET-28c and expressed in E. coli strain BL21(DE3). The recombinant N-terminal His-tagged proteins were purified to near homogeneity by immobilized metal affinity chromatography using $\mathrm{Ni}$ NTA resin. The purified proteins, on resolving in SDSPAGE when visualized in Coomassie Brilliant Blue stained gels, exhibited bands at $37.3 \pm 1.7 \mathrm{kDa}(n=4)$ and $39.1 \pm 1.2 \mathrm{kDa}(n=4)$ for $M t$ MetAPla and $M t M e-$ tAP1c, respectively. The authenticity of the expressed proteins was further confirmed by Western blotting using anti-His antibody (data not shown). MtMetAP1a and MtMetAP1c displayed maximum activity with MetGly-Met-Met and Met-Ala-Ser respectively. The enzymatic specificity for the terminal methionine residue was confirmed by using Gly-Gly-Ala as the substrate and as expected both the enzymes were unable to hydrolyze it (Figure 1A). Furthermore, using different peptides as substrates revealed that at least a tripeptide is the prerequisite for their functionality, since both the enzymes showed almost negligible activity with the dipeptide Met-Gly.

Activities of purified enzymes (1.7 nM for MtMetAP1a or $0.038 \mathrm{nM}$ for $M t$ MetAP1c) as a function of increasing concentrations (0.75-8 mM) of substrate (Met-Gly-MetMet for MtMetAP1a or Met-Ala-Ser for MtMetAP1c) yielded typical Michaelis-Menten curves (Figure 1B). Interestingly, kinetic parameters determined by fitting the data to Michaelis-Menten equation for both the enzymes for their preferred substrate indicated that they were active (Table 1 ; see $K_{\mathrm{m}}$ and $k_{\text {cat }}$ values with Met-Gly-Met-Met for $M t$ MetAP1a and Met-Ala-Ser for MtMetAP1c; considering recombinant His-tagged proteins). Interestingly, using Met-Ala-Ser as the substrate for both the enzymes the catalytic efficiency of MtMetAP1c was strikingly high ( 350-fold) compared to that of the MtMetAP1a (Table 1; $k_{\text {cat }} / K_{\mathrm{m}}=\sim 3 \mathrm{mM}^{-1} \mathrm{~s}^{-1}$ as opposed to $\left.\sim 1156 \mathrm{mM}^{-1} \mathrm{~s}^{-1}\right)$. Thus, our result is in consonance with a recent report that $M t$ MetAP1c is catalytically more efficient compared to MtMetAP1a [20]. Expectedly, both the enzymes exhibited a linear increase in activity as a function of increasing protein concentrations $(r=0.997$ or 0.991 ; Figure $1 \mathrm{~B}$, insets at both left and right panels).

Since MetAPs are known as dinuclear metalloproteases, we also monitored the mycobacterial enzyme activities in response to EDTA, a metal ion chelator. As 
A.

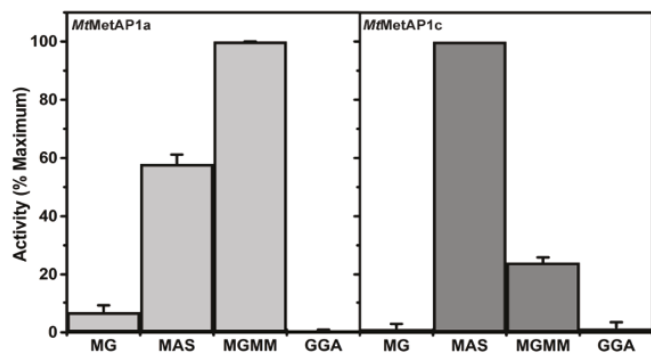

B.
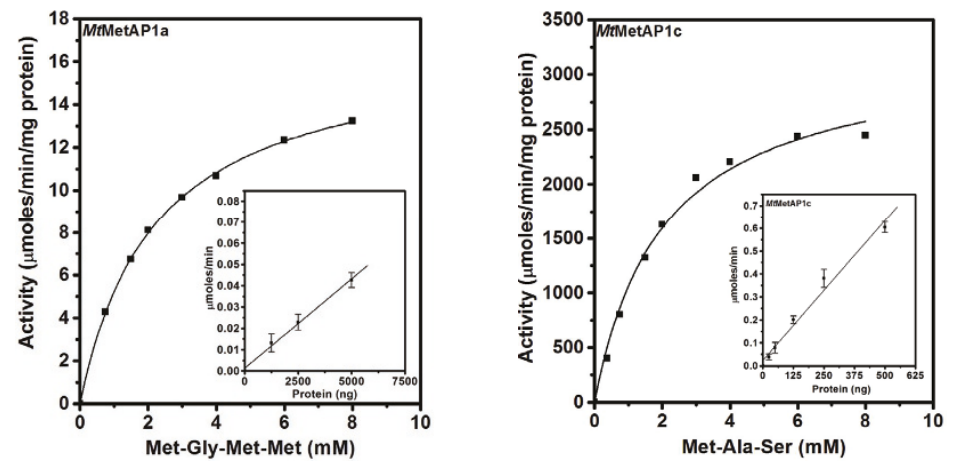

C.
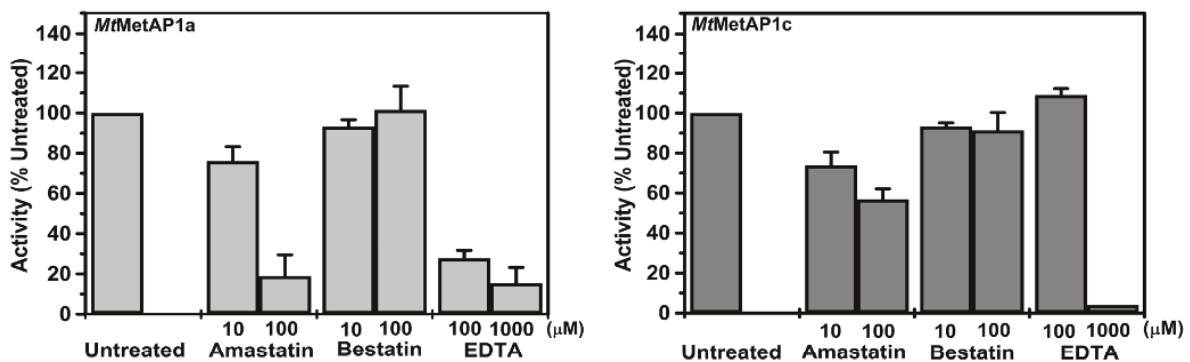

D.
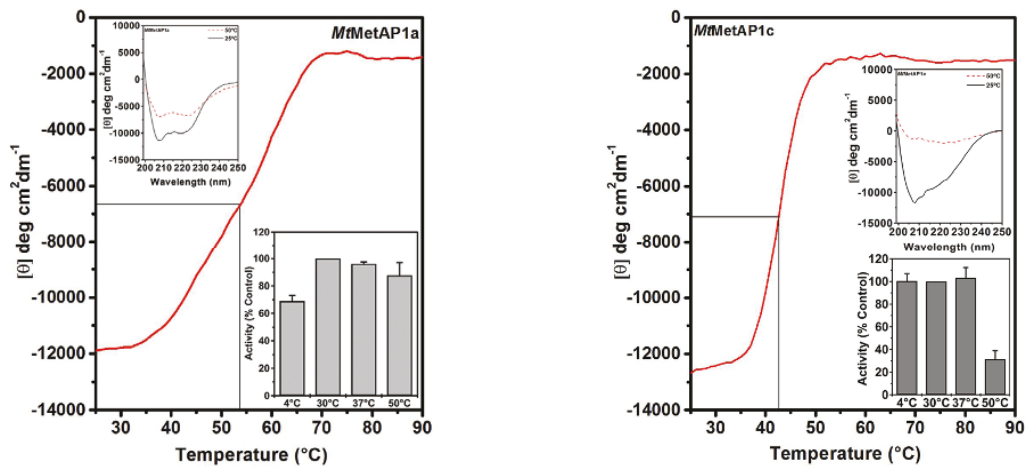

Figure 1 MtMetAP1a and MtMetAP1c are enzymatically active. (A) Methionine aminopeptidase activity with different substrates. Enzyme activity of the two methionine aminopeptidases was determined using different substrates (4 mM) as indicated and MtMetAP1a (1.7 nM) or MtMetAP1C (0.038 nM) of purified protein as mentioned in the methods. Notations used: MG, Met-Gly; MAS, Met-Ala-Ser; MGMM, Met-Gly-MetMet; GGA, Gly-Gly-Ala. (B) Kinetic analysis of methionine aminopeptidase activity of MtMetAP1s. Kinetic analysis of methionine removal ability of MtMetAP1a (left) was carried out by using $1.7 \mathrm{nM}$ of purified protein with increasing concentration of Met-Gly-Met-Met as substrate. The reaction was monitored for $15 \mathrm{~min}$. $0.038 \mathrm{nM}$ of purified protein was incubated for $5 \mathrm{~min}$ with increasing concentration of Met-Ala-Ser as substrate to determine the kinetic parameters of MtMetAP1c (Right). Insets, effect of increasing amount of protein on the enzyme activity. (C) Effect of different inhibitors and chelator on MtMetAPs activity. MetAP1s were preincubated for $15 \mathrm{~min}$ at room temperature with the indicated amount of the inhibitors/EDTA and then the activity assay was performed. (D) Effect of temperature on MtMetAP1s. The thermal unfolding was performed at the rate of $1^{\circ} \mathrm{C} / \mathrm{min}$ and the change in the CD signal was monitored at $208 \mathrm{~nm}$. Left and right panels represent the thermal denaturation graphs for MtMetAP1a and MtMetAP1C respectively. Upper insets show the absorption spectra of MtMetAP1a and MtMetAP1C monitored at $25^{\circ} \mathrm{C}$ and $50^{\circ} \mathrm{C}$. Lower insets show the effect of preincubation for $10 \mathrm{~min}$ at indicated temperatures on the activity of two MtMetAP1s. MtMetAP1a and MtMetAP1C are depicted at (left) and (right) respectively. The assay was carried out at $30^{\circ} \mathrm{C}$ after preincubation. 
Table 1 Kinetic parameters of MtMetAPs

\begin{tabular}{ccccc}
\hline System & $\boldsymbol{K}_{\mathrm{m}}(\mathrm{mM})$ & $\boldsymbol{k}_{\mathrm{cat}}\left(\mathbf{s}^{-1}\right)$ & $\boldsymbol{k}_{\mathrm{cat}} / \boldsymbol{K}_{\mathrm{m}}\left(\mathrm{mM}^{-1} \mathbf{s}^{-1}\right)$ & No. of experiments \\
\hline MtMetAP1a (MGMM) & $2.85 \pm 0.69$ & $9.63 \pm 1.42$ & $3.47 \pm 0.7$ & 3 \\
\hline MtMetAP1a (MAS) & $3.3 \pm 0.35$ & $11.17 \pm 0.97$ & $3.32 \pm 0.18$ & 4 \\
\hline MtMetAP1c (MAS) & $1.36 \pm 0.25$ & $1516 \pm 174$ & $1156 \pm 317$ & 4
\end{tabular}

Enzyme assays were carried out as described under 'Methods' following the incubation of purified MtMetAP1a (1.7 nM/reaction) or MtMetAP1c (0.038 nM/ reaction) proteins with different concentrations $(0.75-8 \mathrm{mM})$ of Met-Ala-Ser (MAS) or Met-Gly-Met-Met (MGMM) as substrate. $K_{\mathrm{m}}$ and $V_{\text {max }}$ values were calculated from Non-linear regression analysis by fitting the data to Michaelis-Menten equation, and the results are expressed as mean \pm SD. For calculating $k_{\text {cat }}$ values, the molecular mass of recombinant enzyme(s) was considered as $29.5 \mathrm{kDa}$ (for MtMetAP1a) or $33.1 \mathrm{kDa}$ (for MtMetAP1c). Mean \pm SD for $k_{\text {cat }} / K_{\mathrm{m}}$ was determined after calculating it for individual experiment.

expected, metal ion chelator affected the activities of both the enzymes. However, compared to that used for $M t$ MetAP1c enzyme activity of MtMetAP1a was inhibited at a lower concentrations of EDTA (Figure 1C). Leucine aminopeptidase inhibitors like amastatin and bestatin, have already been shown to inhibit MetAP activity by binding to its metal centre [7]. As shown in Figure $1 \mathrm{C}$, amastatin affected both $M t$ MetAP1a and $M t$ MetAP1c enzyme activities; magnitude of inhibition, however, varied considerably between them (compared to untreated control, $\sim 80 \%$ decrease in $M t$ MetAP1a as opposed to $\sim 45 \%$ in $M t$ MetAP1c with $100 \mu \mathrm{M}$ of amastatin). Bestatin, on the other hand, had no effect on the enzymatic activities of both the proteins within the concentration range tested in our experimental conditions.

We further addressed the adaptability of MtMetAP1a and $M t$ MetAP1c enzymes to different temperatures. For this purpose, both the enzymes following incubation at different temperatures $\left(4^{\circ}\right.$ or $30^{\circ}$ or $37^{\circ}$ or $50^{\circ} \mathrm{C}$ for $10 \mathrm{~min}$ ) were assayed at $30^{\circ} \mathrm{C}$ for their activities. The maximum activity for both the enzymes was noticed between $30^{\circ}-37^{\circ} \mathrm{C}$. Interestingly, $M t$ MetAP1a retained $\sim 85 \%$ of its activity at $50^{\circ} \mathrm{C}$ as opposed to $\sim 25 \%$ by the $M t$ MetAP1c compared to that observed at $30^{\circ} \mathrm{C}$ (insets showing enzyme activities in left and right panels of Figure 1D). This observation led to the postulation that alteration in the enzyme activity might be occurring as a result of heating and this would very likely cause structural changes in both the proteins. This possibility was explored by incubating both the proteins to $50^{\circ} \mathrm{C}$ and comparing their far-UV CD spectra between 190$250 \mathrm{~nm}$. MtMetAP1a retained (> 50\%) of its secondary structure on heating at $50^{\circ} \mathrm{C}$ while $M t$ MetAP1c was unfolded (compare insets showing CD spectrum in left and right panels of Figure 1D). In fact, determination of $T_{m}$ of both the proteins by $\mathrm{CD}$ spectroscopy yielded values of $53.6^{\circ} \mathrm{C}$ for $M t$ MetAP1a and $42.7^{\circ} \mathrm{C}$ for $M t$ MetAP1c (Figure 1D). These findings, therefore, established the difference in the adaptive ability of $M t$ MetAP1a to high temperature compared to that of the MtMetAP1c and bring an end to the argument about the temperature tolerance of the MtMetAP1s [17,20]. Thus, all these lines of evidence implicated the existence of subtle differences in the behaviour of two mycobacterial MetAPs.

\section{Contribution of active site residues on MtMetAP1 enzyme activity}

Nucleotide derived amino acid sequence alignment of $M t$ MetAP1a with $M t$ MetAP1c revealed $~ 41 \%$ identity (Figure 2A) and the crystal structure of $M t$ MetAP1c (PDB ID: 1YJ3) has already been resolved. Since MtMetAP1a did not show any significant identity with any other protein in the PDB database, we used MtMetAP1c as the template for modelling the structure of this metalloprotease [9]. The modelled structure of $M t \mathrm{Me}-$ tAP1a was validated by PROCHECK and it shows that 98\% residues are in the most favoured regions of Ramachandran plot. The monomer of each protein consists of two pairs of $\alpha$-helices ( $\alpha 1$ to $\alpha 4$ ) packed on the either side of the central antiparallel $\beta$-sheet ( $\beta 3$ and $\beta 4$ ). Interestingly, $\sim 55 \%$ of the structure comprised of loops connecting the secondary structural elements. However, the 40 amino acid long $\mathrm{N}$-terminal extension of $M t \mathrm{Me}$ tAP1c, which is devoid of any secondary structural element, lies across the surface of its catalytic domain (Figure 2B).

Structural analysis predicted the presence of His-88, His-193 and Glu-219 in the active site of MtMetAP1a, while residues like Asp-106, Asp-117, Glu-250 and Trp236 are lining the perimeter of the active site. The presence of homologous residues in MtMetAP1c implies that the active site of both the proteins is essentially conserved (Figure 2A). To gain an insight on their contribution towards the enzyme activity, we generated several point mutants (H88A, H193A, D117A, E219V, W236L for MtMetAP1a and H114A, H212A, D131A, E238A, W255L for MtMetAP1c). Interestingly, the variants do not show any appreciable enzymatic activity even on using 10-fold excess protein compared to that of the wild-type (Figure 2C). In fact, mutating W236L in $M t$ MetAP1a and W255L in MtMetAP1c led to complete loss in the activity (Figure 2C), which is in contrast to the report available with MetAP1 of E. coli [22]. Expression of all the variants, however, was authenticated by Western blotting using anti-His antibody (insets, Figure $2 C)$. To examine the effect of mutations on the secondary and tertiary structures of the $M t$ MetAP1s, the CD spectral studies were performed. Far-UV CD spectrum 


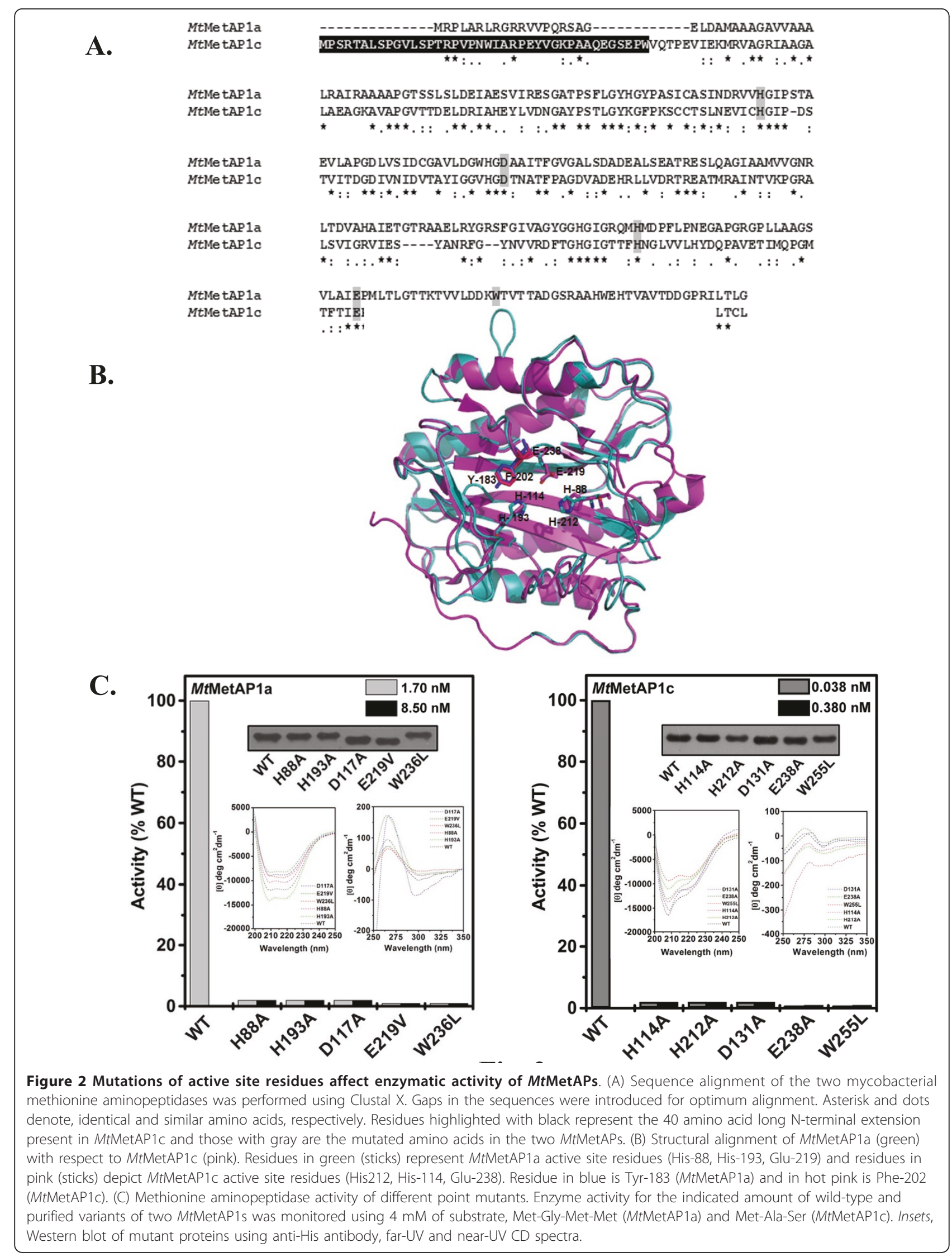


of the mutant proteins of MtMetAP1a revealed that H88A, D117A, E219V and W236L show reduction in helical content. The trend of the data in the region of 200-210 nm suggests that the band with negative mean residue ellipticity at lower wavelengths has reduced signal strength presumably owing to the conversion of some helical regions to less ordered structures (Figure 2C, left panel, inset). Interestingly, mutant H193A shows greater helicity than the wild-type protein. Far-UV CD spectral studies of wild-type MtMetAP1c and its variants revealed that in D131A although there is no significant reduction in the mean residue ellipticity at the 200-210 $\mathrm{nm}$ range, it decreased at the $220-225 \mathrm{~nm}$ range (Figure $2 \mathrm{C}$, right panel, inset). On the other hand, in H114A and E238A reduction in band intensity was observed at both 200-210 nm and 220-225 nm. In H212A and W255L the band intensities at the 200-210 $\mathrm{nm}$ as well as in 220-225 nm were further reduced (Figure 2C, right panel, inset). Thus, the mutations affected secondary structure of both the proteins and changes observed in the near-UV CD spectra indicated alteration in their aromatic environment (insets of Figure 2C, see both left and right panels).

\section{Role of N-terminal extension of MtMetAP1c on the enzyme activity}

The presence of 40 amino acid $\mathrm{N}$-terminal extension although not unusual among MetAP1s, its contribution towards the enzymatic activity is not known as yet [23-25]. To elucidate this aspect, a series of $\mathrm{N}$-terminal deletion variants for $M t$ MetAP1c were generated (Figure 3A) and their enzyme activity was monitored (Figure 3B). Surprisingly, compared to the wild-type, deletion constructs $(\Delta 2-10, \Delta 2-15, \Delta 2-20, \Delta 2-30$ and $\Delta 2-40)$ displayed either drastic decrease or no enzymatic activity (Figure $3 \mathrm{~B}$ ). Even use of 10 fold higher amounts of proteins in our assay, $\Delta 2-10$ or $\Delta 2-15$ exhibited only $30 \%$ activity while $\Delta 2-20$ or $\Delta 2-30$ or $\Delta 2-40$ had no activity (Figure $3 \mathrm{~B}$ ). Thus, our results argue that the catalytic domain alone is not sufficient for the enzymatic function of $M t$ MetAP1c.

$M t$ MetAP1c variants, like $\Delta 2-20$ or $\Delta 2-30$ or $\Delta 2-40$, which did not show any enzyme activity, when stained with Coomassie Brilliant Blue after resolving in SDSPAGE, displayed a progressive loss in the purity of the proteins with the increase in the length of deleted regions (Figure 3C, upper panel). The authenticity of these mutant proteins was confirmed by Western blotting using anti-His antibody (Figure 3C, lower panel). The effect of mutation was evident by the presence of contaminating bands in the Ni-NTA purified samples (Figure 3C, upper panel) and even reduced protein yield ( $\sim \mathrm{mg}$ for $\Delta 2-20 / \Delta 2-30 / \Delta 2-40$ as opposed to $\sim 9 \mathrm{mg}$ in wild-type average yield from 1 litre culture of $E$. coli cells). Analysis of its crystal structure revealed that the
$\mathrm{N}$-terminal extension present in $M t$ MetAP1c wraps around the surface of its catalytic domain in contiguous crevice [9]. Hence, its truncation as a result of deletion might have exposed the hydrophobic residues and thereby destabilized the protein. This has been manifested presumably by exhibiting altered proteolytic property of $M t$ MetAP1c variants and/or led to acquiring the tendency to associate with other proteins [9].

Interestingly, reduction in the enzymatic activity was also observed in $\Delta 2-10$ and $\Delta 2-15$ variants despite the fact that the Ni-NTA purified proteins appear to be similar in profile as has been observed with wild-type. The far-UV CD spectra showed that they $(\Delta 2-10$ and $\Delta 2-15)$ are folded like the wild-type protein (Figure 3D). A slight alteration observed in the near-UV CD spectra for the $\Delta 2-15$ variant (Figure $3 \mathrm{E}$ ) was very likely the result of alteration in the micro-environment of Trp present at the amino acid position 20. Nonetheless, it is apparent from our results that the first 15 amino acids of $M t$ MetAP1c are important for the catalytic activity of the enzyme.

\section{Role of Val-18 and Pro-19 on MtMetAP1c enzyme activity}

To elucidate, the presence of any conserved residues between amino acid 15-20 of MtMetAP1c, we aligned the amino acid sequence of the $\mathrm{N}$-terminal extension region of the $M t$ MetAP proteins from Gram positive bacteria. Multiple sequence analysis revealed that Val-18 and Pro-19 are two highly conserved residues in different MetAPs (Figure 4A). To investigate their role, mutants replacing these two residues, one at a time (V18A, V18G, P19A, P19G) or both at the same time (V18AP19A and V18GP19G) were generated and the enzymatic activities of the recombinant proteins were monitored. Relative to wild type, V18A protein had $\sim 30 \%$ activity while P19A and P19G exhibited $\sim 65 \%$ and $35 \%$ activity respectively. On the other hand, V18G, V18AP19A and V18GP19G variants were devoid of any enzymatic activity (Figure 4B). Use of 10-fold excess of protein in assays, V18A, P19A and P19G mutants displayed activities almost at par (78\%-112\%) with the wild-type. However, use of V18G, V18AP19A and V18GP19G proteins even at increasing amounts in assays had hardly any activity (Figure 4B). These results indicated that Val-18 and/or Pro-19, the residues present in $\mathrm{N}$-terminal extension (not in the catalytic domain) may contribute towards the enzymatic activity of $M t$ MetAP1c. Further, to monitor whether variation in the activity of the mutant proteins could be due to structural changes, far-UV CD studies were performed. The analysis of CD spectra revealed that mutations caused alteration in secondary structure of all the variants (Figure 4C). Compared to the wild type, mutation of Val-18 or Pro-19 (V18A, P19G, V18AP19A) resulted 


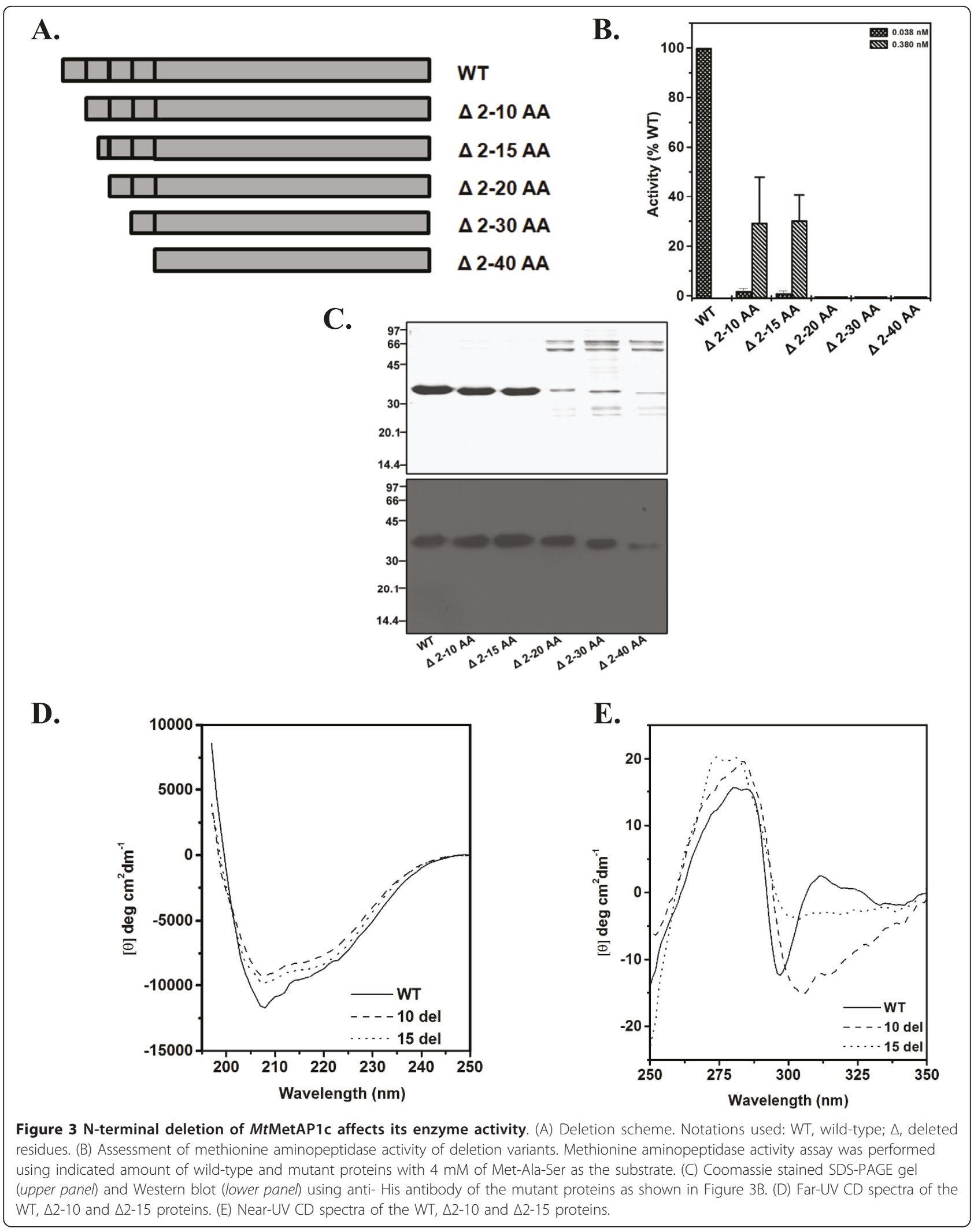


A.

M tb
M bovis
M marinum
M avium
M paratuberculosis
M leprae
S coelicolor
S scabies
R erythropolis
N farcinica
G bronchialis
C diphtheriae
C glutamicum
B mcbrellneri
L xyli

---MPSRT--ALSPGVLSPTRPVPNWIARPEYVGKPAAQEGS-EPWVQTPEVIEKMRVAG ---MPSRT--ALSPGVLSPTRPVPNWIARPEYVGKPAAQEGS-EPWVQTPEVIEKMRVAG ---MPART--ALSPGVLSPMRSVPKWIARPEYVGKPTAREGT-EPWVQTPEVIEKMRVAG ---MPART--ALSPGELSPTLPVPARIPRPEYVGKPTAREGS-EPWVQTPEVIEKMRVAG ---MPART--ALSPGALSPTLPVPARIPRPEYVGKPTAREGS-EPWVQTPEVIEKMRVAG ---MPART--ALSPGFLSPTLPVPAWIPRPEYVGKPTAQEGS-ESWVQTPEVVEKMRVAG ---MSGQS--LLVPGELSPTRSVPGNIRRPEYVGKPAPTPYT-GPEVQTPETVEAMRVAG ---MSGQS--LLAPGKLSPTRTVPGHIRRPEYVGKPAPTPYT-GPEVQTPETVEAMRIAG ---MSVRT--PLVPGTVSPVLAVPSKIERPEYAWKPTAKEGN-E PWVQTPETIEAMRIAS ---MSVRTRQPLVPGTPTPIREVPRSIERPEYAWKKTAKEGS-EPWVQTPETIEKMRIAC ---MPVRA--PLSPGVVSPTRPVPDSIERPEYAWKSTVNEGH-EPWVQTPETIEKVRIAG ---MAITR-EPLKPGHPTPIREVPAYIDRPEYVWKDEVQEAIGEPFIQTPETIEAMREAS MVTMSKMR-APLVPGIPTPIREVPAHIERPEYVWKDEVQEAIGEPFVQAPEVIEKMRETS ---MTSIG--NLTKGTVSPQLSVPSSIPRPEYVGKREPTEGL-GGNMYTDEEIERVRIAG ---MPKDSTGHLIPGRVSASRPVPSHIPQPEYVGKAGPAPSD-RGDVYSAEEIALIRESA

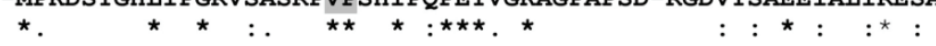

B.
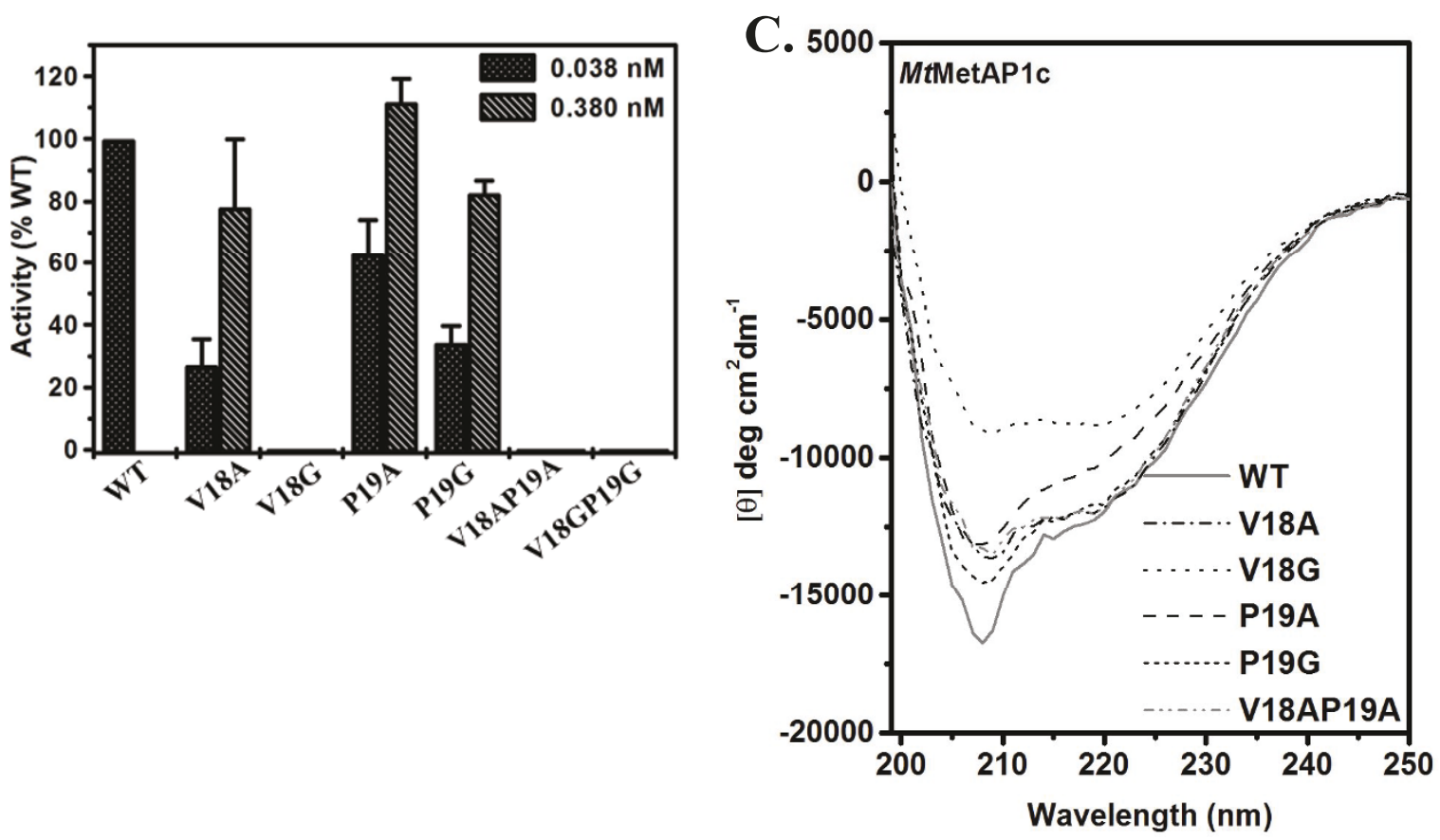

Figure 4 Val-18 and Pro-19 at N-terminal extension are crucial for MtMetAP1c enzyme activity. (A) Sequence alignment of MetAP1c from different gram positive bacteria. Notations used with accession number in parantheses: M tb-Mycobacterium tuberculosis (P0A5J2); M bovisMycobacterium bovis (P0A5J3); M avium-Mycobacterium avium (A0QJ09); M marinum-Mycobacterium marinum (B2HJQ5); M paratuberculosisMycobacterium paratuberculosis (Q73VS7); M leprae-Mycobacterium leprae (Q9CBU7); S coelicolor-Streptomyces coelicolor (Q9RKR2); S scabiesStreptomyces scabies (C9ZHA6); R erythropolis-Rhodococcus erythropolis (COZY62); N farcinica-Nocardia farcinica (Q5YSA3); G bronchialis-Gordonia bronchialis (DOLBG0); C diphtheriae-Corynebacterium diphtheriae (Q6NGL5); C glutamicum-Corynebacterium glutamicum (Q6M437); B mcbrellneriBrevibacterium mcbrellneri (D4YNZ0); L xyli-Leifsonia xyli subsp. xyli (Q6AFH6). (B) Effect of mutations on the MtMetAP1c enzyme activity. The indicated amounts of wild-type and mutant proteins were used to monitor the enzyme activity with $4 \mathrm{mM}$ Met-Ala-Ser as the substrate. (C) FarUV CD spectra of the different mutant proteins.

in the reduction of the negative band intensity in the region of 205-208 $\mathrm{nm}$ of the mutant proteins (Figure 4C). In the variant P19A, the reduction in band intensity was also observed at $222 \mathrm{~nm}$ (in addition to 205-208 $\mathrm{nm})$, thereby indicating that the helical content was reduced. In V18G significant reduction was observed both at 205-208 $\mathrm{nm}$ and $222 \mathrm{~nm}$. Thus, these results suggested the importance of these two residues (Val-18 and Pro-19) exclusively and mutually towards the enzymatic activity of $M t$ MetAP1c. 
To have an idea on how the Val-18 and Pro-19 of $M t$ MetAP1c influenced the activity of the enzyme, we used crystal structure of MtMetAP1c to perform the Molecular dynamic (MD) simulation studies by introducing point mutation(s) at the site of interest (see 'Methods'). Four MD simulations were performed in explicit solvent conditions to examine the effect of specific mutations on overall structure and on the interactions of amino acids lining the active site of the protein. Comparison of the trajectories between wild-type and double mutant (V18GP19G) showed that overall fold of mutant protein is retained (Figure 5A). However, specific and drastic changes in the positions of active site residues were observed (Figures $5 \mathrm{~B}$ and $5 \mathrm{C}$ ). The conformational changes that initiated from the site of mutation (Val-18, Pro-19) propagated to the active site and displaced His-114 as well as affected His-212 and Glu238. Analysis of trajectories of single mutants (V18G and P19A) illustrated that stereo chemical structural changes similar to that observed in double mutant (V18GP19G) were present in V18G (Figure 5C). On the contrary, MD simulation results of P19A appeared much similar to that of the wild-type but the presence of differential population of the ensemble at different time could possibly explain the reduction in the activity of this mutant protein (Figure $5 \mathrm{C}$ right panel). Thus, the results of our MD simulation studies support our biochemical observations.

\section{Discussion}

MetAPs represent a unique class of metalloproteases that catalyze the co-translational removal of N-terminal methionine residue from the elongating polypeptide chain during the process of protein synthesis [2]. Since MetAP action in both prokaryotes and eukaryotes is mandatory during nascent protein synthesis, the importance of this enzyme has long been realized. Though the presence of two MetAP1s was known with the availability of the M. tuberculosis genome sequence, both of them (MtMetAP1a and MtMetAP1c) are active has been shown recently by others $[17,19,20]$ and also in this study. However, it is still not known whether they are merely complementing each other for their functionality and therefore redundant within the genome or their presence is because of the specific needs of the bacterium. Recently, it has been reported that MtMetAP1a knock down caused $\sim 75 \%$ viability of mycobacteria while elimination of $M t$ MetAP1c resulted in 95\% survival [20]. Since this enzyme from different sources has been considered as a potential drug target, identification of inhibitors against these enzymes, particularly for M. tuberculosis MtMetAP1a is in progress [20]. However, the initial step of structure-activity relationship between these two proteins has not been addressed properly. In this context, to carry out systematic study of these two enzymes from $M$. tuberculosis, we have attempted here to analyze MetAP1s to elucidate subtle differences in their characteristics.

Our results indicated that $M t$ MetAP1c had strikingly high enzyme turnover rate with the same substrate (MAS) compared to MtMetAP1a ( 350-fold more; Table 1), although they had different substrate preferences (Figure 1A). The outcome of our CD as well as activity assays with these mycobacterial enzymes illustrate that MtMetAP1a can sustain high temperature (up to $50^{\circ} \mathrm{C}$ ) compared to $M t$ MetAP1c. In fact, $\mathrm{T}_{\mathrm{m}}$ value calculated based on $\mathrm{CD}$ spectra for $M t$ MetAP1a was $53.6^{\circ} \mathrm{C}$ as opposed to $42.7^{\circ} \mathrm{C}$ for $M t$ MetAP1c (Figure 1D). To get an insight into the cause of such differential behaviour of the two enzymes, structure of $M t$ MetAP1a was modelled and compared with the available structure of $M t$ MetAP1c (Figure 2B). We observed that the active site residues in both the $M t$ MetAP1s are essentially same, though their arrangement in space is different (Figure 2B). Furthermore, these amino acids are crucial because any alteration in them (for both the enzymes) yielded an inactive protein (Figure 2C). Thus it is logical to presume that this difference in the arrangement may be responsible for the alteration in their activity/functionality.

Sequence analysis revealed that the remarkable feature of $M t$ MetAP1c compared to $M t$ MetAP1a, is the presence of 40 amino acid long $\mathrm{N}$-terminal extension. It has been suggested that this extension may be involved in the interaction of $M t$ MetAP1c with the ribosome [9]. In ScMetAP1 and HsMetAP2 deletion of N-terminal extension did not significantly alter the catalytic efficiency of the enzymes [23-25]. However, such deletion in ScMetAP1 reduced its efficiency in rescuing the slow growth phenotype of a map mutant [26]. Interestingly, the zinc finger motif present in the $\mathrm{N}$-terminal extension of ScMetAP1 has been shown to be involved in its association with the ribosome [26]. In HsMetAP1, on the other hand, these sequences have been implicated for the interaction of the enzyme with substrates and inhibitors [25]. This led us to explore the role of the $\mathrm{N}$-terminal extension present in MtMetAP1c towards the activity of the enzyme. We constructed a series of deletion mutants removing nine $(\Delta 2-10)$, fourteen $(\Delta 2-15)$, nineteen $(\Delta 2$ $20)$, twenty-nine $(\Delta 2-30)$ and thirty-nine $(\Delta 2-40)$ amino acids from the amino terminal end of the MtMetAP1c (Figure 3A). Enzyme assays with these constructs using even 10 fold excess of proteins compared to the wildtype revealed that there was a considerable loss in activity in $\Delta 2-10$ or $\Delta 2-15$ variants and no activity at all in mutants, like $\Delta 2-20$ or $\Delta 2-30$ or $\Delta 2-40$ (Figure $3 B$ ). Intriguingly, following resolving in SDS-PAGE, analysis of the deletion constructs in Coomassie Brilliant Blue stained gels reflected that purification profile of $\Delta 2-10$ or $\Delta 2-15$ 


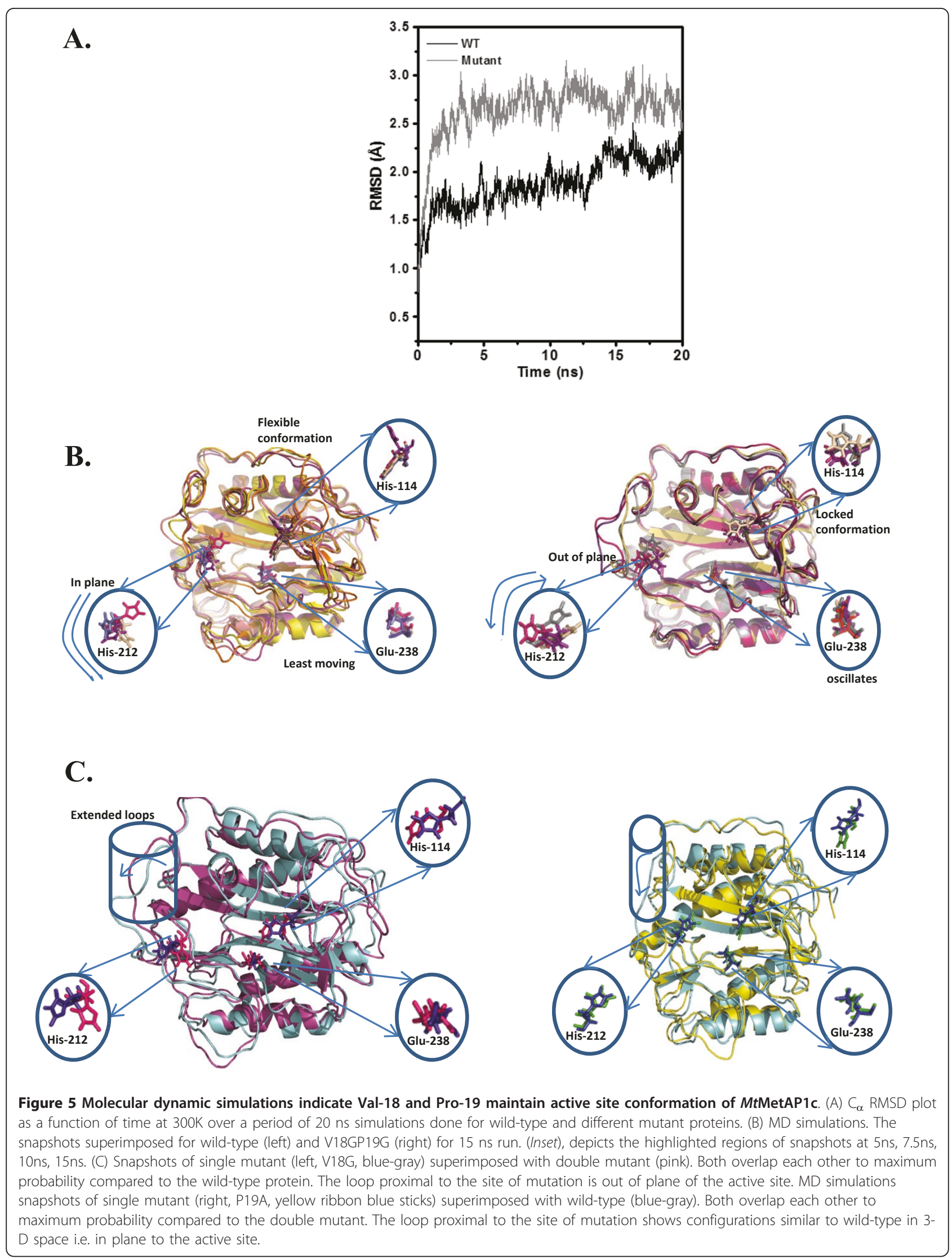


mutants was similar to that of the wild-type but variants like $\Delta 2-20, \Delta 2-30$ and $\Delta 2-40$ exhibited loss in purity of the proteins (Figure 3C, upper panel). Hence, it seems logical to postulate that the amino acid residues between 15 and 20 of $M t$ MetAP1c are crucial for its activity. Perhaps, deletion of residues beyond 19 from the $\mathrm{N}$-terminal end of $M t$ MetAP1c renders the enzyme unstable or exposes its hydrophobic patches, thereby increasing its tendency to associate with the other proteins. In fact, evaluation of structural changes through far-UV and near-UV CD spectra revealed that up to 15 residues from the $\mathrm{N}$-terminal extension of $M t$ MetAP1c are dispensable for the folding of the protein (Figure 3D) but required for its activity (Figure 3B). Thus, our results argue that the $\mathrm{N}$-terminal extension is important for the catalytic activity of $M t$ MetAP1c protein, which is unlike the reports available with $S c$ MetAP1, HsMetAP1 and $H s$ MetAP2 [23-25].

To identify the critical residue(s) for the activity of the protein, we analyzed the sequence of MetAPs from different Gram positive bacteria with N-terminal extension and found the presence of conserved Val-18 and Pro-19 in between amino acid residues 15 and 20 (Figure 4A). This observation, prompted us to create point mutations at $18^{\text {th }}$ and $19^{\text {th }}$ position of $M t$ MetAP1c (one at a time or together with type-to-type/drastic substitutions) and examine their effect on the activity of the enzyme. While V18A and P19A were partially active, V18AP19A did not show any activity. On the other hand, P19G exhibited partial activity but neither V18G nor V18GP19G were active (Figure 4B). Further, to assess if these mutations resulted in any structural alterations, far-UV CD studies were carried out. Interestingly the mutation caused alteration in the secondary structure of the protein. Thus, our results argue the importance of these two residues (Val-18 and Pro-19) exclusively and mutually towards the enzymatic activity of $M t$ MetAP1c. It appears very likely that the structural alterations that occurred due to mutation at Val-18 and/or Pro-19 of MtMetAP1c affected the active site conformation of the protein. In fact, MD simulations (both $5 \mathrm{~ns}$ and $50 \mathrm{~ns}$ ) indicated that the conformational changes generated at the site of mutation (V18GP19G and V18G) propagated via connecting loops and helices to the enzyme active site resulting in the alteration in the movement/positioning of residues like His-114, His-212 and Glu-238 which are critical for the enzyme activity as revealed in our biochemical studies (Figure 2C). These variations in the V18GP19G or V18G mutant proteins presumably made the active site environment unfavourable for any activity. Thus, our results illustrate that residue(s) without being in the active site of an enzyme is capable of modulating its activity, which does not seem to be unusual $[27,28]$.

\section{Conclusion}

Our findings unequivocally emphasize that $\mathrm{N}$-terminal extension of $M t$ MetAP1c contributes towards the functionality of the enzyme by regulating active site residues through "action-at-a-distance" mechanism and this is presumably its unique function in $M t$ MetAP1c, which we are reporting for the first time. Since Val-18 and Pro-19 are conserved residues throughout the Gram positive bacterial MetAP1s with N-terminal extension, it remains to be seen whether they are universal in contributing towards the functionality of the enzyme.

\section{Methods \\ Materials}

Restriction/modifying enzymes were obtained from New England Biolab. All other fine chemicals including MetGly, Met-Ala-Ser, Met-Gly-Met-Met, Gly-Gly-Ala were procured from Sigma Chemical Company. Ni-NTA resin (Qaigen), ECL Western blotting detection kit, PCR DNA/gel band purification kit, protein molecular weight markers (GE Healthcare) and Herculase fusion DNA polymerase (Stratagene) were commercially available. Oligonucleotides used in this study were custom synthesized (IDT/Ocimum Biosolutions/Sigma).

\section{DNA manipulation and generation of MtMetAP-mutants}

Genes encoding two MetAP1, mapA (Rv0734) and mapB (Rv2861c) of M. tuberculosis H37Rv (virulent strain) exhibited $100 \%$ identity at the nucleotide level with its avirulent strain (H37Ra). In this study, genomic DNA isolated [29] from M. tuberculosis strain H37Ra was used for PCR amplification of mapA and mapB genes. For this purpose, gene specific primers incorporating restriction sites were designed (primers CK74 with HindIII and CK140 with NheI sites for mapA; primers CK64 with NdeI and CK65 with HindIII sites for mapB; see Additional file 1, Table S1 for primer sequences) based on published genome sequence [30] and PCR reaction was carried out using Herculase fusion DNA polymerase following manufacturer's recommended protocol. This was followed by cloning of genes at NheI/ HindIII (for mapA) or NdeI/HindIII (for mapB) sites in expression vector (pET-28c) using standard protocols [31] to obtain pET-mapA or pET-mapB construct. PCR was also employed for generation of different mutations (H88A, H193A, D117A, E219V and W236L for MtMetAP1a and H114A, H212A, D131A, E238A, W255L, V18A, V18G, P19A, P19G, V18AP19A, V18GP19G for $M t$ MetAP1c) including deletion mutants $(\Delta 2-10, \Delta 2-15$, $\Delta 2-16, \Delta 2-17, \Delta 2-18, \Delta 2-19, \Delta 2-20, \Delta 2-30, \Delta 2-40)$. For each point mutation two external (CK74/CK140 and CK64/CK65 for mapA and mapB respectively) and two internal primers (incorporating mutation) were designed 
(Additional file 1, Table S1). Two sets of primary (pETmapA/pET-mapB as the template) and one set of secondary (mixture of primary reaction products as the template) PCR reactions were carried out for each mutation. For constructing deletion mutants, pET-mapB was used as template with two set of primers, one primer incorporating NdeI site (excluding $\mathrm{N}$-terminal region to be deleted) and another was external primer (CK65). All these constructs including the wild-type (in pET-28c) were individually transformed into E. coli strains DH5 $\alpha$ to build up DNA and in BL21 (DE3) for expression/purification of His-tagged proteins. All mutations were confirmed by sequencing using an automated DNA sequencer.

\section{Expression and purification of recombinant proteins} Cells harboring pET-mapA or pET-mapB or different mutant constructs were grown overnight $\left(15 \mathrm{~h}\right.$ at $\left.37^{\circ} \mathrm{C}\right)$ in LB broth $(50 \mu \mathrm{g} / \mathrm{ml}$ kanamycin) and induced with $0.4 \mathrm{mM}$ IPTG at $\mathrm{OD}_{600}$ of $\sim 0.8$. Cells were harvested after $12 \mathrm{~h}$ following incubation at $16^{\circ} \mathrm{C}$, resuspended in lysis buffer (100 mM Tris, pH 7.5 containing $300 \mathrm{mM} \mathrm{NaCl}$ for $M t$ MetAP1a or $200 \mathrm{mM} \mathrm{NaCl}$ for MtMetAP1c, $10 \mathrm{mM}$ imidazole, $1 \mathrm{mM}$ phenylmethylsulfonyl fluoride, $1 \mu \mathrm{g} / \mathrm{ml}$ of pepstatin and $1 \mu \mathrm{g} / \mathrm{ml}$ of leupeptin or inhibitor cocktail, Roche) and sonicated. The supernatant fraction was further loaded on a Ni-NTA affinity column, washed with 10 bed volumes of $100 \mathrm{mM}$ Tris $\mathrm{pH} 7.5$ containing $300 \mathrm{mM}$ (for $M t$ MetAP1a) or $200 \mathrm{mM}$ (for MtMetAP1c) $\mathrm{NaCl}$ with $20 \mathrm{mM}$ imidazole. The purified protein(s) was eluted with elution buffer comprising of $100 \mathrm{mM}$ Tris, $\mathrm{pH}$ 7.5 containing either $300 \mathrm{mM} \mathrm{NaCl} / 250 \mathrm{mM}$ imidazole (for $M t$ MetAP1a) or $200 \mathrm{mM} \mathrm{NaCl} / 150 \mathrm{mM}$ imidazole (for $M t$ MetAP1c). Following removal of imidazole by dialysis at $4^{\circ} \mathrm{C}$ for $\sim 14 \mathrm{~h}$ (dialysis buffer: $100 \mathrm{mM}$ Tris, $\mathrm{pH} 7.5$ with either $300 \mathrm{mM} \mathrm{NaCl}$ for MtMetAP1a or $150 \mathrm{mM}$ $\mathrm{NaCl}$ for $M t$ MetAP1c; buffer changed: 4 times), protein was estimated [32] and stored at $-80^{\circ} \mathrm{C}$ until used.

\section{Methionine aminopeptidase activity}

MetAP activity was measured by a colorimetric assay performed at $30^{\circ} \mathrm{C}$ in a microtiter plate by monitoring the absorbance of oxidized o-dianisidine at $440 \mathrm{~nm}$ [33]. Since the assay system involves the use of $\mathrm{CoCl}_{2}$, we determined its optimal amount ( $2 \mathrm{mM}$ for $M t$ MetAP1a and $0.2 \mathrm{mM}$ for $M t$ MetAP1c) to be used for the assessment of enzyme activity at our experimental conditions. We found use of $2 \mathrm{mM} \mathrm{CoCl}_{2}$ did not inhibit $M t \mathrm{Me}$ tAP1a enzyme activity and similar amount has also been used for E. coli MetAP enzyme assay [34]. Briefly, in a $100 \mu$ l reaction volume $M t$ MetAP1a (1.7 $\mathrm{nM} /$ reaction) or $M t$ MetAP1c $(0.038 \mathrm{nM} /$ reaction) protein was mixed with a reaction mixture consisting of $100 \mathrm{mM}$ Tris- $\mathrm{HCl}$
$\mathrm{pH}$ 7.5, $0.2 \mathrm{mM}$ (for MtMetAP1c) or $2 \mathrm{mM}$ (for MtMetAP1a) $\mathrm{CoCl}_{2}, 0.1 \mathrm{mg} / \mathrm{ml}$ o-dianisidine, 3 units of horse radish peroxidase, 0.5 units of $\mathrm{L}$-amino acid oxidase and 0.75-8 mM substrate (Met-Ala-Ser or Met-Gly-MetMet). The activity of the enzyme was monitored in an ELISA plate reader for 2-15 min. The values obtained were corrected by subtracting the blank readings (no significant difference was noticed when assays were carried out with all ingredients except either substrate or protein) and $\mu \mathrm{mol}$ of product released was calculated by using the extinction coefficient [35] of oxidised o-dianisidine as $10580 \mathrm{M}^{-1} \mathrm{~cm}^{-1}$.

\section{Western blotting}

Purified proteins $(1 \mu \mathrm{g}$ protein/slot) were resolved in $12 \%$ SDS-PAGE and transferred to nitrocellulose membranes $(0.45 \mu \mathrm{m})$ using a mini-transblot apparatus (BioRad) for Western blotting. Membranes were stained with Ponceau $\mathrm{S}$ to ensure transfer, processed using antiHis/anti-mouse IgG and detected through ECL detection system following manufacturer's (GE Healthcare) recommended protocol.

\section{CD spectroscopy}

CD spectra of $M t$ MetAP1a and MtMetAP1c were recorded in a Jasco J-810 spectropolarimeter before and after thermal denaturation. Measurements in the farultraviolet region (190-250 nm) were performed on protein solutions $(0.15-0.3 \mathrm{mg} / \mathrm{ml}$ in $20 \mathrm{mM}$ Tris, $\mathrm{pH} 7.5$ and $150 \mathrm{mM} / 300 \mathrm{mM} \mathrm{NaCl}$ ) employing a cell with path length of $0.1 \mathrm{~cm}$ at $25^{\circ} \mathrm{C}$. The protein samples were heated at a rate of $3^{\circ} \mathrm{C} / \mathrm{min}$ up to $50^{\circ} \mathrm{C}$ and the spectra were recorded at $25^{\circ} \mathrm{C}$ and $50^{\circ} \mathrm{C}$. For calculating $\mathrm{T}_{\mathrm{m}}$, $M t$ MetAP1a and MtMetAP1c were heated in the thermoelectric cell of the $C D$ spectrophotometer at the fixed rate of $1^{\circ} \mathrm{C} / \mathrm{min}$ and the thermal denaturation curves were recorded at $208 \mathrm{~nm}$. Measurements in near-ultraviolet region $(250-350 \mathrm{~nm})$ were carried out using cell with path length of $1 \mathrm{~cm}$ at $25^{\circ} \mathrm{C}$ on protein solutions $(0.3-0.5 \mathrm{mg} / \mathrm{ml}$ in $20 \mathrm{mM}$ Tris, $\mathrm{pH} 7.5$ and $150 \mathrm{mM} / 300 \mathrm{mM} \mathrm{NaCl}$ ). The mean residue ellipticity $[\theta]$ was calculated using a mean residue molecular mass of $110 \mathrm{Da}$. Each spectrum reported is an average of ten scans. Blank spectra of aqueous buffer were used to correct the observed spectra.

\section{Bioinformatic analysis}

Nucleotide derived amino acid sequence of $M t$ MetAP1c was compared with non-redundant database using BLAST [36]. The multiple sequence alignment of the retrieved sequences was carried out using ClustalX [37] with default values for gap opening and extension penalties. 


\section{Molecular modelling}

The crystal structure of $M t$ MetAP1c (PDB ID: 1YJ3) [9] served as the template for modeling of MtMetAP1a using Modeller 9v7 program and model was selected on the basis of DOPE score [38-40]. The PROCHECK validated model was energy minimised using LEap module of AMBER 9 package $[41,42]$. Structures of different mutants (V18G, P19G, and V18GP19G) were generated using $M t$ MetAP1c as the template and residue replacement editor in PYMOL. The structure of all the mutants were also energy minimized.

\section{Molecular dynamics simulations}

All MD simulations were performed with AMBER 9.0 and FF03 forcefield [43]. The protein was embedded in the TIP3P water box [44], which approximately extended $10 \AA$ in each direction from the peripheral surface of the protein to any periodic box edge with unit box dimensions of $18.774 \times 18.774 \times 18.774$ A . Periodic boundary conditions were applied and the entire system (solvent with protein) was energy minimized. Initial equilibration was monitored for $1 \mathrm{~ns}$ and the production MD simulation was then run at $300 \mathrm{~K}$, maintained using Langevin weak coupling algorithm [45]. The simulation trajectory was calculated using heavy atom harmonic position SHAKE [46]. Simulation was continued till 50 ns with an integration step of 2 fs and snapshots were retained every $10 \mathrm{ps}$ for further analysis. MD trajectories were analyzed using the PTRAJ module and structures were visualized using VMD molecular visualization program [47].

\section{Data analysis}

Unless mentioned otherwise, reproducibility of each experiment throughout this study was checked at least three times and results were calculated as Mean \pm SD.

\section{Additional material}

Additional file 1: Table S1. Supplementary Table showing sequences of the primer used in this study.

\footnotetext{
Abbreviations

anti-his: antibody against histidine-tag; IPTG: isopropyl- $\beta$-D-

thiogalactopyranoside; HsMetAP: Homo sapiens Methionine aminopeptidase; MD: molecular dynamic simulations; ScMetAP1: Saccharomyces cerevisiae Methionine aminopeptidase 1

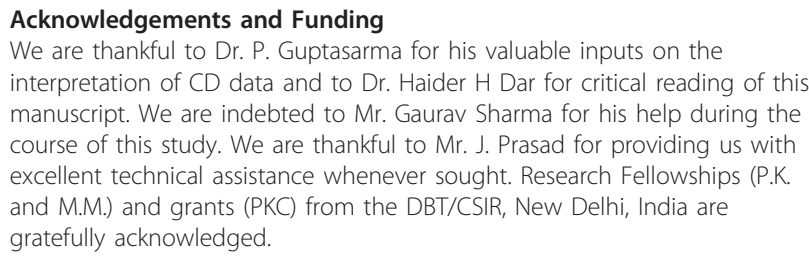
interpretation of CD data and to Dr. Haider $\mathrm{H}$ Dar for critical reading of this manuscript. We are indebted to Mr. Gaurav Sharma for his help during the course of this study. We are thankful to Mr. J. Prasad for providing us with excellent technical assistance whenever sought. Research Fellowships (P.K. and M.M.) and grants (PKC) from the DBT/CSIR, New Delhi, India are gratefully acknowledged.

\section{Authors' contributions}

PK and PKC conceived the study, planned the experiments, analyzed results and wrote the paper. PK did all wet lab experiments. MM and SK carried out Molecular modelling and Molecular dynamic simulation studies, interpreted results and wrote respective portions of the paper. All authors read and approved the final manuscript.

Received: 17 April 2011 Accepted: 5 July 2011 Published: 5 July 2011

\section{References}

1. Giglione C, Boularot A, Meinnel T: Protein N-terminal methionine excision. Cell Mol Life Sci 2004, 61(12):1455-1474.

2. Giglione C, Fieulaine $S$, Meinnel T: Cotranslational processing mechanisms: towards a dynamic 3D model. Trends Biochem Sci 2009, 34(8):417-426.

3. Wiltschi $B$, Merkel $L$, Budisa $N$ : Fine tuning the $\mathrm{N}$-terminal residue excision with methionine analogues. Chembiochem 2009, 10(2):217-220.

4. Solbiati J, Chapman-Smith A, Miller JL, Miller CG, Cronan JE Jr: Processing of the $\mathrm{N}$ termini of nascent polypeptide chains requires deformylation prior to methionine removal. J Mol Biol 1999, 290(3):607-614.

5. Meinnel T, Mechulam Y, Blanquet S: Methionine as translation start signal: a review of the enzymes of the pathway in Escherichia coli. Biochimie 1993, 75(12):1061-1075.

6. Arfin SM, Kendall RL, Hall L, Weaver LH, Stewart AE, Matthews BW, Bradshaw RA: Eukaryotic methionyl aminopeptidases: two classes of cobalt-dependent enzymes. Proc Natl Acad Sci USA 1995, 92(17):7714-7718.

7. Lowther WT, Matthews BW: Metalloaminopeptidases: common functional themes in disparate structural surroundings. Chem Rev 2002, 102:4581-4608.

8. Bradshaw RA, Brickey WW, Walker KW: N-terminal processing: the methionine aminopeptidase and $\mathrm{N}$ alpha-acetyl transferase families. Trends Biochem Sci 1998, 23(7):263-267.

9. Addlagatta A, Quillin ML, Omotoso O, Liu JO, Matthews BW: Identification of an $\mathrm{SH} 3$-binding motif in a new class of methionine aminopeptidases from Mycobacterium tuberculosis suggests a mode of interaction with the ribosome. Biochemistry 2005, 44(19):7166-7174.

10. Alvarado JJ, Nemkal A, Sauder JM, Russell M, Akiyoshi DE, Shi W, Almo SC, Weiss LM: Structure of a microsporidian methionine aminopeptidase type 2 complexed with fumagillin and TNP-470. Mol Biochem Parasitol 2009, 168(2):158-167.

11. Hu X, Addlagatta A, Lu J, Matthews BW, Liu JO: Elucidation of the function of type 1 human methionine aminopeptidase during cell cycle progression. Proc Natl Acad Sci USA 2006, 103(48):18148-18153.

12. Yeh JR, Ju R, Brdlik CM, Zhang W, Zhang Y, Matyskiela ME, Shotwell JD, Crews CM: Targeted gene disruption of methionine aminopeptidase 2 results in an embryonic gastrulation defect and endothelial cell growth arrest. Proc Natl Acad Sci USA 2006, 103(27):10379-10384

13. Chen X, Chong CR, Shi L, Yoshimoto T, Sullivan DJ Jr, Liu JO: Inhibitors of Plasmodium falciparum methionine aminopeptidase $1 \mathrm{~b}$ possess antimalarial activity. Proc Natl Acad Sci USA 2006, 103(39):14548-14553.

14. Chang SY, McGary EC, Chang S: Methionine aminopeptidase gene of Escherichia coli is essential for cell growth. J Bacteriol 1989, 171(7):4071-4072.

15. Miller CG, Kukral AM, Miller JL, Movva NR: pepM is an essential gene in Salmonella typhimurium. J Bacteriol 1989, 171(9):5215-5217.

16. Li $\mathrm{X}$, Chang $\mathrm{YH}$ : Amino-terminal protein processing in Saccharomyces cerevisiae is an essential function that requires two distinct methionine aminopeptidases. Proc Natl Acad Sci USA 1995, 92(26):12357-12361.

17. Zhang $X$, Chen S, Hu Z, Zhang L, Wang H: Expression and characterization of two functional methionine aminopeptidases from Mycobacterium tuberculosis H37Rv. Curr Microbiol 2009, 59(5):520-525.

18. Chai SC, Lu JP, Ye QZ: Determination of binding affinity of metal cofactor to the active site of methionine aminopeptidase based on quantitation of functional enzyme. Anal Biochem 2009, 395(2):263-264.

19. Lu JP, Chai SC, Ye QZ: Catalysis and inhibition of Mycobacterium tuberculosis methionine aminopeptidase. J Med Chem 2010 53(3):1329-1337.

20. Olaleye O, Raghunand TR, Bhat S, He J, Tyagi S, Lamichhane G, Gu P, Zhou J, Zhang Y, Grosset J, Bishai WR, Liu JO: Methionine aminopeptidases from Mycobacterium tuberculosis as novel antimycobacterial targets. Chem Biol 2010, 17(1):86-97. 
21. Lu JP, Ye QZ: Expression and characterization of Mycobacterium tuberculosis methionine aminopeptidase type 1a. Bioorg Med Chem Lett 2010, 20(9):2776-2779

22. Chiu CH, Lee CZ, Lin KS, Tam MF, Lin LY: Amino acid residues involved in the functional integrity of Escherichia coli methionine aminopeptidase. J Bacteriol 1999, 181(15):4686-4689

23. Zuo S, Guo Q, Ling C, Chang YH: Evidence that two zinc fingers in the methionine aminopeptidase from Saccharomyces cerevisiae are important for normal growth. Mol Gen Genet 1995, 246(2):247-253.

24. Yang G, Kirkpatrick RB, Ho T, Zhang GF, Liang PH, Johanson KO, Casper DJ, Doyle ML, Marino JP Jr, Thompson SK, Chen W, Tew DG, Meek TD: Steadystate kinetic characterization of substrates and metal-ion speciicities of the full-length and N-terminally truncated recombinant human methionine aminopeptidases (type 2). Biochemistry 2001, 40:10645-10654

25. Li JY, Chen LL, Cui YM, Luo QL, Gu M, Nan FJ, Ye QZ: Characterization of full length and truncated type I human methionine aminopeptidases expressed from Escherichia coli. Biochemistry 2004, 43(24):7892-7898.

26. Vetro $\mathrm{JA}$, Chang $\mathrm{YH}$ : Yeast methionine aminopeptidase type 1 is ribosome-associated and requires its $\mathrm{N}$-terminal zinc finger domain for normal function in vivo. J Cell Biochem 2002, 85(4):678-688.

27. Ginsberg AM, Spigelman M: Challenges in tuberculosis drug research and development. Nat Med 2007, 13(3):290-294

28. Saxena R, Kanudia P, Datt M, Dar HH, Karthikeyan S, Singh B, Chakraborti PK: Three consecutive arginines are important for the mycobacterial peptide deformylase enzyme activity. J Biol Chem 2008, 283(35):23754-23764.

29. Chaba R, Raje M, Chakraborti PK: Evidence that a eukaryotic-type serine/ threonine protein kinase from Mycobacterium tuberculosis regulates morphological changes associated with cell division. Eur J Biochem 2002, 269(4):1078-1085.

30. Cole ST, Brosch R, Parkhill J, Garnier T, Churcher C, Harris D, Gordon SV, Eiglmeier K, Gas S, Barry CE, Tekaia F, Badcock K, Basham D, Brown D, Chillingworth T, Connor R, Davies R, Devlin K, Feltwell T, Gentles S, Hamlin N, Holroyd S, Hornsby T, Jagels K, Krogh A, McLean J, Moule S, Murphy L, Oliver K, Osborne J, et al: Deciphering the biology of Mycobacterium tuberculosis from the complete genome sequence. Nature 1998, 393(6685):537-544

31. Sambrook J, Russel D: Molecular Cloning: A Laboratory Manual. 3 edition. Cold Spring Harbor Laboratory Press, Cold spring Harbor, NY; 2001.

32. Bradford MM: A rapid and sensitive method for the quantitation of microgram quantities of protein utilizing the principle of protein-dye binding. Anal Biochem 1976, 72:248-254.

33. Ben-Bassat A, Bauer K, Chang SY, Myambo K, Boosman A, Chang S: Processing of the initiation methionine from proteins: properties of the Escherichia coli methionine aminopeptidase and its gene structure. J Bacteriol 1987, 169(2):751-757

34. Shapiro BA, Gao N, Thresher J, Walkup KG, Whiteaker J: A high-throughput absorbance-based assay for Methionine produced by Methionine aminopeptidase using S-adenosyl-L-methionine synthetase. J Biomol Screen 2011.

35. Frottin F, Martinez A, Peynot P, Mitra S, Holz RC, Giglione C, Meinnel T: The proteomics of N-terminal methionine cleavage. Mol Cell Proteomics 2006 , 5(12):2336-2349.

36. Altschul SF, Madden TL, Schaffer AA, Zhang J, Zhang Z, Miller W, Lipman DJ: Gapped BLAST and PSI-BLAST: a new generation of protein database search programs. Nucleic Acids Res 1997, 25(17):3389-3402.

37. Thompson JD, Gibson TJ, Plewniak F, Jeanmougin F, Higgins DG: The CLUSTAL_X windows interface: flexible strategies for multiple sequence alignment aided by quality analysis tools. Nucleic Acids Res 1997, 25(24):4876-4882.

38. Sali A, Blundell TL: Comparative protein modeling by satisfaction of spatial restraints. J Mol Biol 1993, 234:779-815.

39. Shen MY, Sali A: Statistical potential for assessment and prediction of protein structures. Protein Sci 2006, 15(11):2507-2524.

40. Eramian D, Shen MY, Devos D, Melo F, Sali A, Marti-Renom MA: A composite score for predicting errors in protein structure models. Protein Sci 2006, 15(7):1653-1666.

41. Laskowski RA, MacArthur MW, Moss DS, Thornton JM: PROCHECK: a program to check the stereo chemical quality of protein structures. J Appl Cryst 1993, 26:283-291.

42. Case TADDA, Cheatham TE III, Simmerling CL, Wang J, Duke RE, Luo KMMR, Pearlman DA, Crowley M, Walker RC, Zhang W, Wang B, Hayik ARS,
Seabra KF, Wong F, Paesani X, Wu S, Brozell V, Tsui H, Gohlke LYC, Tan J, Mongan V, Hornak G, Cui P, Beroza DH, Mathews C, Schafmeister WSR, Kollman PA: AMBER 9 University of California, SanFrancisco; 2006.

43. Duan Y, Wu C, Chowdhury S, Lee MC, Xiong G, Zhang W, Yang R, Cieplak P, Luo R, Lee T, Caldwell J, Wang J, Kollman P: A point-charge force field for molecular mechanics simulations of proteins based on condensed-phase quantum mechanical calculations. J Comput Chem 2003, 24(16):1999-2012.

44. Price DJ, Brooks CL: A modified TIP3P water potential for simulation with Ewald summation. J Chem Phys 2004, 121:10096-10103.

45. Futaba DN, Hata K, Yamada T, Hiraoka T, Hayamizu Y, Kakudate Y, Tanaike O, Hatori H, Yumura M, lijima S: Shape-engineerable and highly densely packed single-walled carbon nanotubes and their application as super-capacitor electrodes. Nat Mater 2006, 5(12):987-994.

46. Ryckaert JP, Ciccotti, Berendsen HJC: Numerical integration of the Cartesian equations of motion of a system with constraints: molecular dynamics of n-alkanes. J Comput Phys 1977, 23:327-341.

47. Humphrey W, Dalke A, Schulten K: VMD: visual molecular dynamics. J Mol Graph 1996, 14(1):33-38, 27-38.

doi:10.1186/1471-2091-12-35

Cite this article as: Kanudia et al: Amino-terminal extension present in the methionine aminopeptidase type 1c of Mycobacterium tuberculosis is indispensible for its activity. BMC Biochemistry 2011 12:35.

\section{Submit your next manuscript to BioMed Central and take full advantage of:}

- Convenient online submission

- Thorough peer review

- No space constraints or color figure charges

- Immediate publication on acceptance

- Inclusion in PubMed, CAS, Scopus and Google Scholar

- Research which is freely available for redistribution

Submit your manuscript at www.biomedcentral.com/submit
C) Biomed Central 